war conditions. The new-type electrically driven recording drums for the Milne-Shaw seismographs are proving satisfactory in India. The rotation of the drum is particularly uniform and there is no 'backlash'. This result has been achieved by pivoting the electric motor eccentrically on a spindle, and permitting it to fall by gravity into mesh with the gear attached to the drum. It may be described as a 'floating' contact in place of the usual fixed centres. Difficulties in connexion with the International Seismological Summary are being successfully overcome at Oxford. Jeffreys has investigated the deep earthquake of June 29, 1934, and has obtained from it helpful readings of the receding $(D E)$ branch of $P K P$. The table of $P K P$ has thus been improved and a table also constructed for $s P$. Stoneley makes some very helpful and pertinent remarks concerming the integration of seismograms in connexion with the long-wave phase of earthquakes. There need now be no hesitation in accepting the usual identification of the early part of the long-wave phase (apparent velocities $4 \cdot 4-4 \cdot 0 \mathrm{~km}$./sec.) as Love waves.

\section{Compounding in Locomotive Design}

Mr. W. A. Stanier delivered the presidential address to the Institution of Mechanical Engineers on October 24, when he discussed "The Position of the Locomotive in Mechanical Engineering". Although a standard feature of marine reciprocating design, compounding has not found extensive favour in Europe except in France. In England it has been the subject of repeated trials-no less than 12 per cent of the papers ever read before the Institution are on compounding-and in theory it has obvious advantages over simple expansion. These advantages are specially marked at working pressures higher than $300 \mathrm{lb}$. per sq. in. Attempts in Great Britain have contained defects, condensation causing serious loss, and lack of understanding of the principles of steam flow have often rendered the engines more sluggish than their simple expansion contemporaries. Superheating, which brought fresh life to the compound engine on the Continent, has only been applied to any scale to one British type, the 'Midland' compound; within the limits of its size, good work has been done and is still being done by this class. It has, however, never been modernized as regards its cylinder and valve-gear design, so its actual efficiency is below that of the present-day simple expansion engine. It is also possible to understand now why the French De Glehn compounds, imported by the Great Western Railway in 1903 and 1905, did not give results superior to the simple-expansion designs of Churchward. It is impracticable to combine within the British loading gauge, however, both the large lowpressure cylinders required, and the bearing and crank dimensions required by compound locomotives.

\section{Northern Ecological Association}

THE Northern Ecological Association was founded by the late Mr. R. J. Flintoft, of Goathland, Yorks, who organized workers in various fields of natural science in their own localities in the north of England. Valuable work had been done in this way, and it was felt that the organization should not be allowed to lapse, but should be placed on a permanent basis. Accordingly a special meeting of the Association was held at York on November 23, and it was decided. to re-enact the existing constitution and to adopt the existing name. The officers of the Association are as follows : president, Dr. W. Collinge ; secretary and treasurer, Mr. J. L. Forrest, Eversfield, Goathland, Yorks ; editor, M. Dallman.

\section{Dr. E. N. Miles Thomas}

Dr. E. M. Des.r, Department of Botany, Westfield College, London (at St. Peter's Hall, Oxford) writes : "Dr. E. N. Miles Thomas, who is widely known amongst botanists for her contributions to the study of seedling anatomy, retired from her position as head of the Department of Biology at University College, Leicester, in 1937. Thereafter she occupied a research room at Westfield College (University of London), and for a time continued her many professional activities. Her health, however, was already seriously impaired. The evacuation of the College to Oxford and other difficulties in connexion with the War situation probably added greatly to the overstrain from which she was suffering. Early in 1940 she was found to have lost almost completely her power of memory, a condition which is now unfortunately regarded as permanent, although her general health has somewhat improved. Her research effects are housed at the Jodrell Laboratory, Kөw."

\section{Recent Earthquakes}

IN addition to being recorded on all the seismograms at Kew Observatory, the earthquake of November 25 was recorded on the electrometer record of the rain electrograph. This earthquake, which affected Lisbon, gave very large amplitudes at Kow. The real ground amplitude caused by $P(18 \mathrm{~h} .08 \mathrm{~m} .22 \mathrm{~s}$. U.T.) exceeded $300 \mu$, the amplitude caused by $S$ (18h. 13m. 45s. U.T.) exceeded $800 \mu$ and the maximum may have exceeded $2 \mathrm{~mm}$. A tentative interpretation of the records shows a compression from the southwest (azimuth $233^{\circ}$ ) and an epicentral distance near $3,600 \mathrm{~km}$. The epicentre may thus have been near $28^{\circ} \mathrm{N}$., $29^{\circ} \mathrm{W}$., in the Atlantic Ocean south of the Azores. On December 4 an earthquake of considerable severity was felt at Rangoon though no damage is reported. On December 6 earthquakes were reported from Santiago and from San José in Costa Rica. Considerable damage was reported though full details are not yet available.

The United States Coast and Geodetic Survey, in co-operation with Science Service and the Jesuit Seismological Association, has found the epicentres of the earthquakes of October 3 and October 5. The earthquake of October 3 at $16 \mathrm{~h} .13 \cdot 2 \mathrm{~m}$. U.T. had its epicentre near lat. $40 \cdot 6^{\circ} \mathrm{N}$., long. $124 \cdot 6^{\circ} \mathrm{W}$., which is in northern California in the neighbourhood of Cape Mendocino. On the basis of instrumental reports from seven seismograph stations, the epicentre of the earthquake of October 5 at $10 \mathrm{~h} .11 \cdot 2 \mathrm{~m}$. has been calculated to be lat. $15^{\circ} \mathrm{S}$., long. $173^{\circ} \mathrm{W}$., which is in the Pacific Ocean between the Islands of Samoa and the Fiji Islands. All interpretations and calculations are tentative. 